\title{
Trophic ecology of the facultative symbiotic coral Oculina arbuscula
}

Article in Marine Ecology Progress Series · May 2014

DOI: $10.3354 /$ meps 10750

CITATIONS

6 authors, including:

\section{Miguel Costa Leal}

Eawag: Das Wasserforschungs-Institut des ..

52 PUBLICATIONS 449 CITATIONS

SEE PROFILE

Ricardo Calado

University of Aveiro

132 PUBLICATIONS 1,404 CITATIONS

SEE PROFILE

\section{Christine Ferrier-Pagès}

Monaco Scientific Centre

172 PUBLICATIONS 5,002 CITATIONS

SEE PROFILE

Jens Christian Nejstgaard

Leibniz-Institute of Freshwater Ecology and...

72 PUBLICATIONS 2,061 CITATIONS

SEE PROFILE

Some of the authors of this publication are also working on these related projects: 


\title{
Trophic ecology of the facultative symbiotic coral Oculina arbuscula
}

\author{
Miguel C. Leal ${ }^{1,2, *}$, Christine Ferrier-Pagès ${ }^{3}$, Ricardo Calado ${ }^{1}$, Jay A. Brandes ${ }^{2}$, \\ Marc E. Frischer ${ }^{2}$, Jens C. Nejstgaard ${ }^{2}$ \\ ${ }^{1}$ Departamento de Biologia \& CESAM, Universidade de Aveiro, Campus Universitário de Santiago, 3810-193 Aveiro, \\ Portugal \\ ${ }^{2}$ Skidaway Institute of Oceanography, University of Georgia, 10 Ocean Science Circle, Savannah, Georgia 31411, USA \\ ${ }^{3}$ Centre Scientifique de Monaco, Avenue Saint-Martin 98000, Monaco
}

\begin{abstract}
Symbiotic corals are trophically complex, relying on both auto- and heterotrophy. Here, the nutrition of the temperate facultative symbiotic scleractinian coral Oculina arbuscula was investigated under natural conditions. Nutrition of symbiotic and aposymbiotic colonies during spring and fall was assessed by determining the carbon and nitrogen isotope signature of their tissues, photosynthetic endosymbionts and different potential food sources (plankton and particulate organic matter) in seawater and sediment. The nutrition of symbiotic colonies was primarily derived from their endosymbionts, regardless of the season. However, aposymbiotic colonies of $O$. arbuscula relied preferentially on sediment organic matter as well as pico- and nanoplankton $(<10 \mu \mathrm{m})$. As this small planktonic fraction (that includes phytoplankton) has been overlooked as a potential food source for symbiotic scleractinian corals, this study provides new insights into this feeding mode in these reef-building organisms.
\end{abstract}

KEY WORDS: Heterotrophy $\cdot$ Autotrophy $\cdot$ Symbiosis $\cdot$ Aposymbiotic $\cdot$ Stable isotopes

\section{INTRODUCTION}

Nutrition of symbiotic corals relies largely on organic compounds supplied by endosymbiotic dinoflagellates, usually from the genus Symbiodinium (hereafter referred to as symbionts) (Porter 1976, Falkowski et al. 1984). Up to $100 \%$ of the metabolic requirements of the coral host is supplied by photosynthetically-fixed carbon translocated from its symbionts under optimal light conditions (Muscatine et al. 1981). Besides autotrophy, corals are also able to feed heterotrophically, particularly by capturing zooplankton and other planktonic organisms (Houlbrèque \& Ferrier-Pagès 2009, Leal et al. 2014a). Experimental studies have shown that feeding increases photosynthesis, respiration and calcification rates in several coral species (e.g. Ferrier-Pagès et al. 2003, Houlbrèque et al. 2003, 2004a, Rodrigues
\& Grottoli 2007). Heterotrophy is also known to play an important role in coral metabolism, particularly under stressful conditions such as when light is limiting or during bleaching events (Anthony \& Fabricius 2000, Grottoli et al. 2006, Palardy et al. 2008, Leal et al. 2013).

There is ample literature on experimental studies of coral nutrition (see review by Houlbrèque \& Ferrier-Pagès 2009). In contrast, field studies assessing the importance of heterotrophy for coral metabolism are limited. This knowledge gap is likely associated with constraints in tracing nutrient fluxes between corals and their constantly changing food environment. Thus, to date only a few studies have assessed the grazing impact of whole coral communities, some by measuring the plankton abundance upstream and downstream of waters flowing above the reef (Glynn 1973, Ribes et al. 2003, Yahel et al. 2005, Houlbrèque 
et al. 2006), others by performing coral gut content dissections (e.g. Sebens et al. 1996, Palardy et al. 2006).

Stable carbon and nitrogen isotope ratios $\left(\delta^{13} \mathrm{C}\right.$ and $\delta^{15} \mathrm{~N}$ ) have been used in laboratory experiments to assess the relative importance of auto- and heterotrophy in coral nutrition. A review of the literature indicates that $\delta^{13} \mathrm{C}$ signatures of corals and their symbionts are generally similar, as it reflects a high degree of nutrient exchange between the 2 partners (e.g. Muscatine et al. 1989, Reynaud et al. 2002), with a slightly more negative value for the coral host that further decreases if heterotrophy becomes the main nutrition mode (Muscatine et al. 2005). The isotopic $\delta^{13} \mathrm{C}$ signature of tropical corals usually varies between -12 and $-16 \%$, although in temperate corals it may reach $-18 \%$ (e.g. Madracis mirabilis) or $-28 \%$ (e.g. Cladocora caespitosa). The $\delta^{15} \mathrm{~N}$ signature of the coral host is usually correlated with the heterotrophic food source, and is more enriched than the symbionts' $\delta^{15} \mathrm{~N}$ signature because of nutrient recycling in the symbiosis (Reynaud et al. 2009). Although isotopes provide information on the trophic level and potential nutritional sources of the coral host, this method has rarely been used in situ to estimate the contribution of auto- and heterotrophy to coral nutrition and compare with potential food sources (e.g. Muscatine et al. 1989, 2005, Alamaru et al. 2009). Moreover, to our knowledge, this approach has never been applied to assess the preferential prey of symbiotic and aposymbiotic corals in situ. As the nutrition of bleached corals may rely significantly on hetero-trophy (Grottoli et al. 2006, Hughes \& Grottoli 2013), it is important to know the natural food sources that support corals in situ, especially as corals face increasing challenges in the future ocean.

The present study focuses on the temperate scleractinian coral Oculina arbuscula. This species is endemic to the temperate waters of the northwestern Atlantic Ocean. O. arbuscula is a facultatively symbiotic species that naturally occurs with and without zooxanthellae, and therefore exhibits considerable nutritional plasticity (Miller 1995, Piniak 2002, Leal et al. 2014b). The aim of this study is to investigate the contribution of auto- and heterotrophy to nutrition in $O$. arbuscula living under different natural conditions and to determine the potential food sources. We hypothesize that the contribution of auto- and heterotrophy to $O$. arbuscula nutrition varies with symbiotic status of the colony, and with season. To address the proposed hypothesis, symbiotic and aposymbiotic coral colonies were sampled, and the isotopic signature of the coral tissue com- pared with that of potential autotrophic (symbionts) and heterotrophic (organic matter in the water column and sediment) food sources.

\section{MATERIALS AND METHODS}

\section{Sampling}

Corals were collected from Gray's Reef National Marine Sanctuary (GRNMS). GRNMS is located off the Georgia coast (USA) between the inner- and midcontinental shelf portion of the South Atlantic Bight (SAB). Coral specimens for this study were collected at $20 \mathrm{~m}$ depth $\left(30.3939^{\circ} \mathrm{N}, 80.8853^{\circ} \mathrm{W}\right)$ under the manager's permit. GRNMS is structured as a ledge system with vertical relief hard-bottom levelling off into a sandy plateau habitat (Hunt 1974). The reef is tidally influenced and seasonally dynamic with respect to temperature, light, turbidity, and nutrients. In addition, because it is relatively shallow it is regularly affected by large storms that often re-suspend the benthos (Hyland et al. 2006).

Coral samples were collected during the spring (May 2012) and fall (October 2012). In each season, a branching portion of 5 symbiotic and 5 aposymbiotic coral colonies were randomly collected by SCUBA divers. Aposymbiotic colonies were usually found in shaded areas close to the ledge. Collected corals were enclosed underwater in a plastic bag containing the surrounding seawater and brought to the laboratory where they were cleaned of epiphytes and sediment. Coral samples were subdivided in 2 , and frozen at $-80^{\circ} \mathrm{C}$. To characterize the isotopic signature of the particulate organic matter (POM) suspended in seawater, five 21 bottles of seawater were sampled near the corals in each season using a Niskin bottle, and transported to the laboratory for filtration. A concentrated sample of large plankton organisms was collected at the sampling site during daytime with a vertical plankton tow (63 $\mu \mathrm{m}$ mesh size) close to the benthic environment. Samples for sediment organic matter (SOM) analysis were taken each season by SCUBA divers near the corals by scraping the upper $1 \mathrm{~cm}$ of the surface sediment into a plastic bag containing surrounding seawater (Riera 1998). The sampling effort of the POM and SOM fractions in each season was performed to provide an overall characterization of the isotopic signature of the potential food sources of $O$. arbuscula and to frame this coral within the food chain, as performed by similar studies with benthic organisms (e.g. Riera et al. 1996, 1999, Ferrier-Pagès et al. 2011, Cocito et al. 2013). 


\section{Laboratory procedures}

No more than 1 wk after sampling, the coral samples were thawed and individually placed in $100 \mathrm{ml}$ beakers (pre-combusted at $480^{\circ} \mathrm{C}$ for at least $4 \mathrm{~h}$ ) containing $20 \mathrm{ml}$ of filtered seawater $(0.7 \mu \mathrm{m})$. The coral tissue of each colony was completely removed from the skeleton with an air pick and homogenized with a Potter tissue grinder (pre-combusted at $480^{\circ} \mathrm{C}$ ). Half of the homogenate was freeze-dried and used to estimate the mean signal of the holobiont (host tissue with its symbionts). The other half of the homogenate was separated into a coral host and a symbiont fraction. For the coral host fraction, the homogenate was centrifuged at $3000 \times g$ for $10 \mathrm{~min}$ at $4^{\circ} \mathrm{C}$ to pellet most of the symbionts. The supernatant was re-centrifuged twice to eliminate the remaining symbionts, transferred to Pyrex Petri dishes and freeze-dried. The absence of symbionts in this fraction was confirmed by microscopic examination. For the symbiont fraction, the pellet obtained by centrifugation was washed several times with filtered seawater until no contamination by host cells was visible upon microscopic examination, and then freeze-dried. Holobiont, host and symbiont fractions were fumigated with $\mathrm{HCl}$ in a closed chamber for $18 \mathrm{~h}$ to remove carbonates and dried at $70^{\circ} \mathrm{C}$ for $24 \mathrm{~h}$, ground to a fine powder and kept dried until subsequent analysis. Isotopic analyses were performed on these 3 sets of samples, with each colony treated individually. The other half of the coral samples were analysed for chlorophyll a (chl a) content and symbiont density. For this purpose, coral tissue was detached as previously described and homogenized in $12 \mathrm{ml}$ of filtered seawater. A $2 \mathrm{ml}$ sub-sample was taken to measure symbiont density following the method of Rocha et al. (2013). The remaining $10 \mathrm{ml}$ sub-samples were centrifuged at $5000 \times \mathrm{g}$ for $10 \mathrm{~min}$ at $4^{\circ} \mathrm{C}$, and the pellet containing the symbionts was re-suspended in $10 \mathrm{ml}$ of $90 \%$ acetone. Pigments were extracted at $4^{\circ} \mathrm{C}$ during the next $24 \mathrm{~h}$. Chl a content was determined with and without acidification in accordance with Parsons et al. (1984) using a 10 AU Turner fluorometer (Turner Designs). Symbiont density and chl a data were normalized to coral surface area using the single wax dipping method (Veal et al. 2010).

Water samples for POM analysis were size fractionated through inverse filtration to avoid cell breakage. The size fractions were: particles $<10 \mu \mathrm{m}$ (pico- and nanoplankton) and particles between 10 and $63 \mu \mathrm{m}$ (large nanoplankton and small micro- plankton). Particles >63 $\mu \mathrm{m}$ (zooplankton) resulted from the plankton tow collection. Each fraction was then filtered onto pre-combusted $25 \mathrm{~mm}$ Whatman $\mathrm{GF} / \mathrm{F}$ filters, and the filters were dried at $70^{\circ} \mathrm{C}$ for $24 \mathrm{~h}$. A fraction of the zooplankton samples was collected on filters and treated as above for stable isotope analysis.

For the measurement of stable isotopic ratios of SOM, particles larger than $63 \mu \mathrm{m}$ were removed by sieving. A sub-sample of approximately $5 \mathrm{~g}$ of the fraction smaller than $63 \mu \mathrm{m}$ was dried at $70^{\circ} \mathrm{C}$ and ground using a mortar and pestle. Afterwards, a subsample of approximately $200 \mathrm{mg}$ was acidified as described for coral samples. Once acidified and dried $\left(70^{\circ} \mathrm{C}\right)$, the sediment was mixed with Milli-Q water and again dried, ground to a fine pounder and dried.

Dried samples of coral, POM and SOM fractions were analysed for $\delta^{13} \mathrm{C}$ and $\delta^{15} \mathrm{~N}$ using a ThermoFisher Delta V plus isotope ratio mass spectrometer coupled to a Thermo Flash elemental analyser (Fry et al. 1992). Internal chitin standards (Sigma) crossstandardized to internal isotopic reference materials were run at the beginning of each run, and for every 10 samples. Average precision of standards and replicate samples for $\delta^{13} \mathrm{C}$ and $\delta^{15} \mathrm{~N}$ was 0.1 and $0.2 \%$, respectively.

\section{Statistical analysis}

Chl a content per coral surface area, symbiont density and chl a content per cell were compared using a 2-way ANOVA, with the categorical factors being symbiotic status (2 levels: symbiotic and aposymbiotic colonies) and season (2 levels: spring and fall). The isotopic signatures of the different samples (holobiont, coral host tissue, symbiont) collected from both seasons (spring and fall) from coral colonies with different symbiotic status (symbiotic and aposymbiotic) were compared using a 3-way ANOVA. Whenever assumptions of normality and homoscedasticity were violated, ANOVA were performed on square-root transformed data. Tukey's HSD test was used when ANOVA revealed significant differences $(p<0.05)$. Isotopic signatures of SOM and different POM size classes were compared separately between seasons using a Student's $t$-test. The theoretical food source of the coral host was calculated taking into account a trophic enrichment of 1 and $3.5 \%$ for $\delta^{13} \mathrm{C}$ and $\delta^{15} \mathrm{~N}$, respectively, following Ferrier-Pagès et al. (2011). All statistical analysis and plots were performed using R software (R Development Core Team 2013). 


\section{RESULTS}

The density and concentration of symbiotic Oculina arbuscula symbionts and chl $a$, respectively, were similar between spring and fall (Fig. 1). Symbiont density and chl a concentration were significantly lower in aposymbiotic colonies compared to symbiotic colonies $(2$-way ANOVA, $p<0.01)$. The amount of chl a per symbiont cell was significantly different between symbiotic and aposymbiotic corals $\left(p<0.05\right.$; symbiotic $=1.33 \pm 0.39$ pg cell $^{-1} ;$ aposymbiotic $=0.54 \pm 0.21 \mathrm{pg} \mathrm{cell}^{-1} ;$ average $\pm \mathrm{SD}$ ).

Carbon $\left(\delta^{13} \mathrm{C}\right)$ and nitrogen $\left(\delta^{15} \mathrm{~N}\right)$ isotopic signatures are shown in Fig. 2 and Table 1. A significant effect of season, symbiotic status and coral fraction (holobiont, coral host, symbionts) was observed in the $\delta^{13} \mathrm{C}$ isotopic signature (Table 2). The $\delta^{13} \mathrm{C}$ was always similar between the holobiont and coral host regardless of symbiotic status (Fig. 2), and similar between the coral host and zooxanthellae in symbiotic colonies for each season. Season had no effect on $\delta^{13} \mathrm{C}$ of the symbionts (Fig. 2), but significantly changed the $\delta^{13} \mathrm{C}$ signature of the holobiont and coral host. This signature was ca. +1 and $+5 \%$ higher in fall than in spring for symbiotic and aposymbiotic corals, respectively (Tukey's HSD, $\mathrm{p}<0.05$ ). The $\delta^{13} \mathrm{C}$ signature of the holobiont and coral host was significantly more negative in aposymbiotic than in symbiotic colonies in spring (Tukey's HSD, $p<0.05$ ). This same signature for the symbionts was similar between symbiotic conditions during both seasons.

A significant effect of season, symbiotic status and holobiont fraction was observed for the $\delta^{15} \mathrm{~N}$ isotopic signature (Table 2). In symbiotic corals, the $\delta^{15} \mathrm{~N}$ iso-

Table 1. $\delta^{13} \mathrm{C}$ and $\delta^{15} \mathrm{~N}$ values (mean $\pm \mathrm{SD}$ ) for the sediment organic matter (SOM) and different size fractions of particulate organic matter (POM) in spring and fall. Significant differences between seasons for each isotopic signature are marked with different letters

\begin{tabular}{|lcccc|}
\hline \multirow{2}{*}{$\begin{array}{l}\text { Potential food } \\
\text { sources }\end{array}$} & \multicolumn{2}{c}{$\delta^{13} \mathrm{C}(\%)$} & \multicolumn{2}{c|}{$\delta^{15} \mathrm{~N}(\%)$} \\
& Spring & Fall & Spring & Fall \\
\hline $\mathrm{SOM}<63 \mu \mathrm{m}$ & $-20.6 \pm 0.2^{\mathrm{a}}$ & $-21.2 \pm 0.3^{\mathrm{b}}$ & $5.5 \pm 0.5$ & $6.1 \pm 0.4$ \\
$\mathrm{POM}<10 \mu \mathrm{m}$ & $-24.6 \pm 0.2^{\mathrm{a}}$ & $-22.4 \pm 0.3^{\mathrm{b}}$ & $4.9 \pm 0.2^{\mathrm{a}}$ & $6.2 \pm 0.3^{\mathrm{b}}$ \\
$\mathrm{POM} 10-63 \mu \mathrm{m}$ & $-24.5 \pm 0.2^{\mathrm{a}}$ & $-19.6 \pm 0.6^{\mathrm{b}}$ & $6.6 \pm 0.1^{\mathrm{a}}$ & $7.3 \pm 0.2^{\mathrm{b}}$ \\
$\mathrm{POM}>63 \mu \mathrm{m}$ & $-22.3 \pm 0.1^{\mathrm{a}}$ & $-17.7 \pm 0.6^{\mathrm{b}}$ & $5.8 \pm 0.4^{\mathrm{a}}$ & $7.5 \pm 0.3^{\mathrm{b}}$ \\
\hline
\end{tabular}
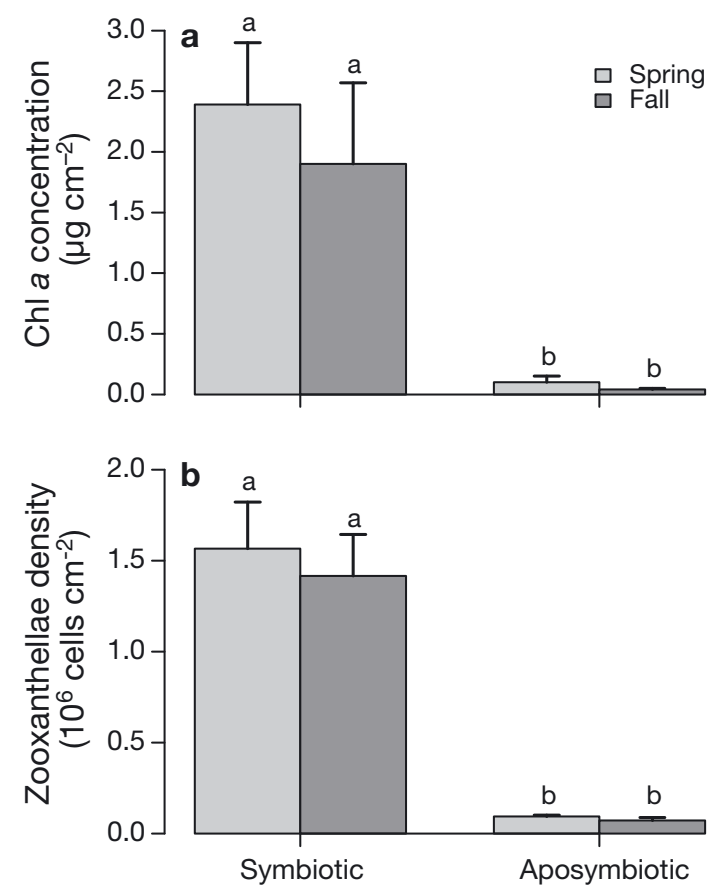

Fig. 1. Oculina arbuscula. (a) Chlorophyll a content ( $\mu \mathrm{g}$ $\mathrm{cm}^{-2}$ ), and (b) symbiont density (cells $\mathrm{cm}^{-2}$ ) in symbiotic and aposymbiotic colonies of $O$. arbuscula during spring and fall. Values are mean $\pm \mathrm{SD}(\mathrm{n}=5)$. Significant differences $(p<0.05)$ are indicated with different letters
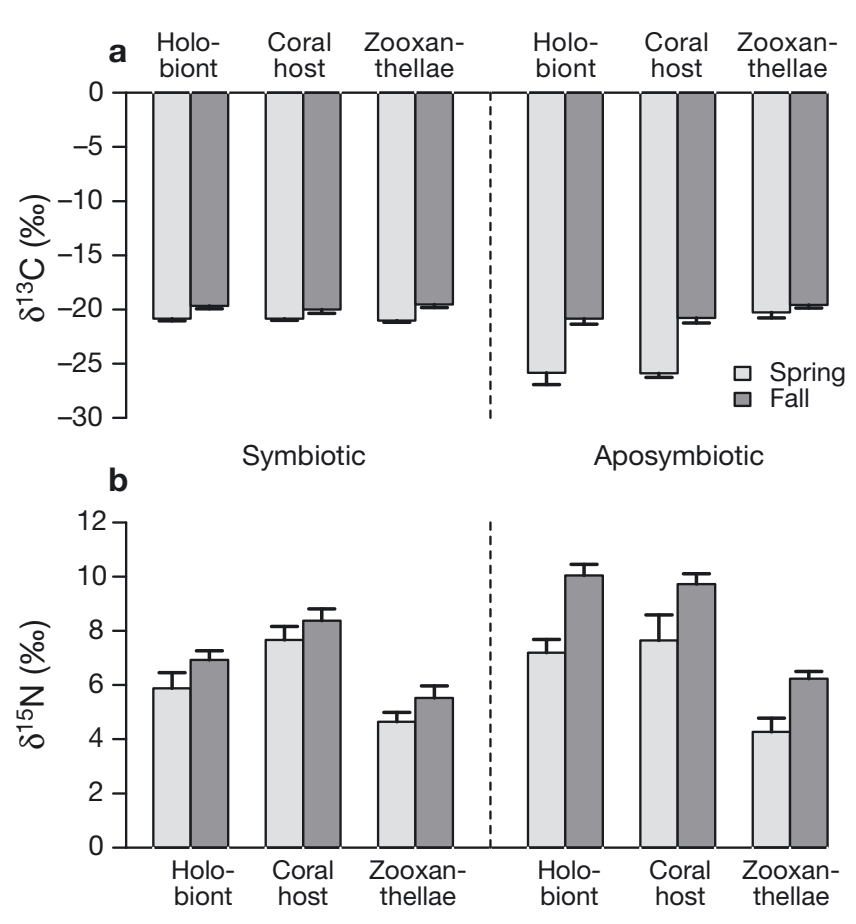

Fig. 2. Oculina arbuscula. (a) $\delta^{13} \mathrm{C}$ and (b) $\delta^{15} \mathrm{~N}$ values of holobiont, coral host tissue and symbionts of symbiotic and aposymbiotic $O$. arbuscula colonies sampled during spring and fall. Values are mean \pm SD $(n=5)$ 
Table 2. Oculina arbuscula. Three-way ANOVA comparing the $\delta^{13} \mathrm{C}$ and $\delta^{15} \mathrm{~N}$ isotopic signatures between holobiont fraction (holobiont, coral host tissue and symbiont), seasons (spring and fall) and symbiotic status of the coral colonies (symbiotic and aposymbiotic)

\begin{tabular}{|c|c|c|c|c|c|}
\hline \multirow[t]{2}{*}{ Factor } & \multirow[t]{2}{*}{$\mathrm{df}$} & \multicolumn{2}{|c|}{$\delta^{13} \mathrm{C}$} & \multicolumn{2}{|c|}{$\delta^{15} \mathrm{~N}$} \\
\hline & & $F$ & $\mathrm{p}$ & $F$ & $\mathrm{p}$ \\
\hline Fraction & 2 & 108.19 & $<0.01$ & 251.91 & $<0.01$ \\
\hline Season & 1 & 426.27 & $<0.01$ & 197.68 & $<0.01$ \\
\hline Symbiotic status & 1 & 261.63 & $<0.01$ & 91.36 & $<0.01$ \\
\hline Fraction $\times$ Season & 2 & 30.43 & $<0.01$ & 4.96 & $<0.05$ \\
\hline Fraction $\times$ Symbiotic status & 2 & 93.14 & $<0.01$ & 30.63 & $<0.01$ \\
\hline Fraction $\times$ Symbiotic status & 1 & 119.39 & $<0.01$ & 43.48 & $<0.01$ \\
\hline Fraction $\times$ Season $\times$ Symbiotic status & 2 & 53.84 & $<0.01$ & 1.33 & 0.27 \\
\hline
\end{tabular}

\section{DISCUSSION}

This study examined the contribution of algal symbionts and external food sources to the carbon and nitrogen balance of the temperate scleractinian coral Oculina arbuscula. The isotopic signatures observed for the different coral fractions and potential food sources confirm that pico- and nanoplankton $(<10 \mu \mathrm{m})$ and SOM largely contribute to the nutrition of $O$. arbuscula in situ. The results of this study also confirmed our 2 hypotheses, as auto- and heterotrophic contributions to $O$. arbuscula topic signature was significantly lower in the holobiont than in the coral host during both seasons (Tukey's HSD, p < 0.05; Fig. 2). In contrast, there were no significant seasonal differences in $\delta^{15} \mathrm{~N}$ signatures of the holobiont and coral host fractions from aposymbiotic colonies (Tukey's HSD, p $=0.76$ and 0.88 , respectively). Overall, the $\delta^{15} \mathrm{~N}$ isotopic signature was always higher in the fall than in the spring for all fractions of the coral holobiont (Fig. 2). Significant differences between symbiotic and aposymbiotic colonies were observed in the fall for the $\delta^{15} \mathrm{~N}$ isotopic signature of coral host (Tukey's HSD, p < 0.05). The $\delta^{15} \mathrm{~N}$ signature was significantly higher in the coral host than in the symbionts during both seasons, for both symbiotic and aposymbiotic colonies (Fig. 2b).

The $\delta^{13} \mathrm{C}$ and $\delta^{15} \mathrm{~N}$ isotopic signatures of SOM were generally lower than POM, and an overall increase in the signature of both isotopes was observed with increasing POM size classes (Table 1). While the $\delta^{13} \mathrm{C}$ isotopic signature of SOM was lower in spring, all POM fractions displayed higher $\delta^{13} \mathrm{C}$ values in this season (Student's $t$-test, $\mathrm{p}<0.05)$. The $\delta^{15} \mathrm{~N}$ isotopic signatures of all POM fractions were significantly higher in the fall (Table 1).

Carbon and nitrogen signatures of the different samples are plotted simultaneously in Fig. 3. In order to identify the preferential nutrition mode of Oculina arbuscula in each season, the theoretical food source is also indicated. A similar pattern in the functioning of symbiotic colonies was observed in both seasons (Fig. 3a,b), with the isotopic signature of the theoretical food source being relatively close to the signature of the symbionts. In aposymbiotic colonies (Fig. 3c,d), the theoretical food source during spring and fall was similar to the smallest POM fraction $(<10$ $\mu \mathrm{m})$, and also to SOM during the fall. nutrition varied with the symbiotic status of the colony and with the season.

The similar $\delta^{13} \mathrm{C}$ isotopic signature of the different fractions (holobiont, coral host and symbiont) in symbiotic colonies suggests high nutrient exchange between the symbionts and the host. However, the isotopic signature for the host and particularly for the symbionts (about $-20 \%$ ) was more negative than is typically reported in tropical symbiotic corals, which usually display higher $\delta^{13} \mathrm{C}$, closer to $-12 \%$ (e.g. Muscatine et al. 1989, Swart et al. 2005). This is probably associated with the highly productive temperate and often turbid waters where Oculina arbuscula occur (Miller 1995). Low light levels influenced the $\delta^{13} \mathrm{C}$ signature, as did the heterotrophic status of the colony (Muscatine et al. 1989, Seemann et al. 2013). Larger heterotrophic contribution may be associated with lower autotrophic inputs due to the relatively low zooxanthellae density present in symbiotic colonies (Fig. 1a) as compared to other tropical and temperate symbiotic corals (e.g. Fitt et al. 2000, Rodolfo-Metalpa et al. 2006, Ferrier-Pagès et al. 2011).

The $\delta^{15} \mathrm{~N}$ isotopic signature of the coral host also indicates a high degree of heterotrophy. Regardless of symbiotic status, the theoretical food source of the coral host had a similar $\delta^{15} \mathrm{~N}$ signature to that of $<10 \mu \mathrm{m}$ POM fraction in both seasons, and also to SOM in fall (Fig. 3). Further, the seasonal changes observed for the isotopic signature of the coral host are likely associated with the seasonality of heterotrophic food sources (Table 1), as the variation of $\delta^{15} \mathrm{~N}$ isotopic signature between spring and fall for the symbiotic $(+0.8 \%$ o) and asymbiotic $(+2.1 \%$ ) coral host followed the same trend of the $<10 \mu \mathrm{m}$ POM fraction $(+1.3 \%$ ). This also supports the hypothesis that the primary nitrogen source for both symbiotic and 


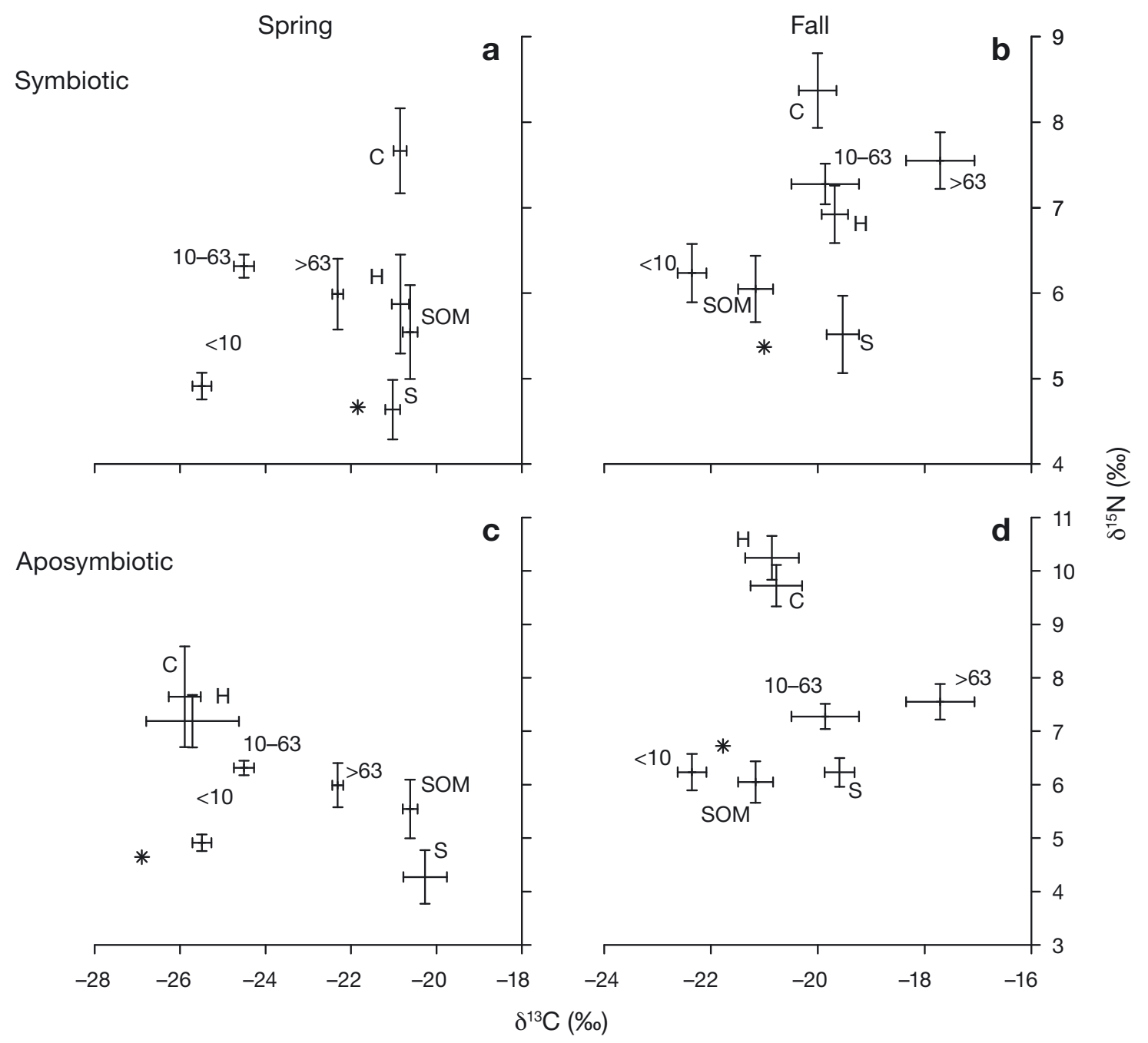

Fig. 3. Oculina arbuscula. $\delta^{13} \mathrm{C}$ versus $\delta^{15} \mathrm{~N}$ (mean $\pm \mathrm{SD}$ ) for symbiotic (a,b) and aposymbiotic (c,d) O. arbuscula, sediment and seawater sampled during spring $(\mathrm{a}, \mathrm{c})$ and fall $(\mathrm{b}, \mathrm{d})$. Asterisks correspond to the theoretical food source of the coral host, taking into account the trophic enrichment of 1 and $3.5 \%$ for $\delta^{13} \mathrm{C}$ and $\delta^{15} \mathrm{~N}$, respectively. $\mathrm{H}=$ holobiont; $\mathrm{C}=$ coral host; $\mathrm{S}=$ symbiont $; \mathrm{SOM}=$ sediment organic matter $;<10=$ seawater organic matter $<10 \mu \mathrm{m} ; 10-63=$ seawater organic matter between 10 and $63 \mu m_{i}>63=$ seawater organic matter $>63 \mu \mathrm{m}$

aposymbiotic colonies derives from heterotrophy (Ferrier-Pagès et al. 2003, Piniak et al. 2003). Moreover, the difference observed for the $\delta^{15} \mathrm{~N}$ isotopic signature among the holobiont fractions (Fig. 2b) is probably due to a higher retention of heavy nitrogen by the host (after prey ingestion), and excretion (and subsequent re-uptake by the zooxanthellae) of light nitrogen from waste products (Reynaud et al. 2009). This nutrient recycling in the symbiosis contributes to the $\delta^{15} \mathrm{~N}$ enrichment of $3 \%$ observed between the coral host and the symbionts observed during both seasons (Fig. 2).

Heterotrophy was the expected nutrition mode of the aposymbiotic colonies (Miller 1995). The large difference between symbionts and coral host and holobiont fractions support the low contribution of autotrophy (Fig. 3c,d). In contrast to the results observed for symbiotic colonies, the $\delta^{13} \mathrm{C}$ isotopic signature of the coral host was significantly lower than that of the symbionts (Fig. 2a). However, this was not detected in asymbiotic colonies during fall. The $\delta^{13} \mathrm{C}$ isotopic signature of asymbiotic Oculina arbuscula in the fall was similar among all coral fractions, and to the results observed for symbiotic corals (Fig. 2a). One possibility is that aposymbiotic colonies sampled in the fall were originally symbiotic and recently bleached. The results could therefore reflect the isotopic signature of the coral in its former symbiotic condition, where both auto- and heterotrophy occur (mixotrophy), together with high nutrient exchange between the host and symbionts. It has been speculated that corals rely on energy reserves from auto- 
trophy when bleached (Grottoli et al. 2004), and that both photoautotrophic and heterotrophic acquired carbon play a crucial role in the recovery from bleaching (Hughes et al. 2010, Hughes \& Grottoli 2013). As autotrophy in $O$. arbuscula has not been considered to be as important as in tropical corals (Muscatine et al. 1989, 2005), it is important to determine to what extent this holds true for this coral in its natural environment. Here, we address this question through calculation of the isotopic signature of the theoretical food source (Fig. 3). Although the exact number for isotopic fractionation for this coral species is unknown, results for symbiotic $O$. arbuscula show that the isotopic signature of the theoretical food source is similar to the symbionts in symbiotic corals and to certain fractions of organic matter available in the environment (Fig. 3a,b). While it is not clear which of these fractions is the preferential food source for the symbiotic colonies due to the contribution of autotrophy to the coral's nutrition, the theoretical food source of these colonies in the fall was also similar to the isotopic signature of SOM.

Aposymbiotic Oculina arbuscula was notably similar to the $<10 \mu \mathrm{m}$ POM fraction in spring (Fig. 3c) and also to SOM in fall (Fig. 3d). This reliance on picoand nanoplankton during both seasons has only been reported in few studies, as this small planktonic fraction has been overlooked as a potential food source for scleractinian corals (e.g. Houlbrèque et al. 2006, Naumann et al. 2009, Ferrier-Pagès et al. 2011). While the analysis performed in this study does not allow us an accurate characterization of the organisms present in the $<10 \mu \mathrm{m}$ POM, it is known that this fraction is mainly composed of bacteria, phototrophic and heterotrophic flagellates, diatoms and cyanobacteria (Lalli \& Parsons 1997). In the SAB region, phototrophs account for 60 to $90 \%$ of the carbon biomass of pico- and nanoplankton, particularly diatoms that compose 30 to $70 \%$ of the phototrophic community (Verity et al. 1993, 1996). In recent laboratory experiments, Leal et al. (2014a) demonstrated that symbiotic $O$. arbuscula is able to feed on microalgae from 4 to $12 \mu \mathrm{m}$. Herbivory is a poorly documented feature of symbiotic corals (Houlbrèque \& Ferrier-Pagès 2009) that has already been reported for several asymbiotic soft corals (Fabricius et al. 1995, 1998) and only more recently has been described for a reduced number of symbiotic corals (Tremblay et al. 2012, Seemann et al. 2013). While the molecular trophic markers used by Leal et al. (2014a) provide information on prey capture, the present study provides information on the coral food sources that were assimilated over time. This supports the hypothesis that small planktonic organisms, including phytoplankton, may play a relevant contribution to the nutrition of scleractinian corals such as $O$. arbuscula.

In conclusion, this study suggests that SOM and the planktonic fraction $<10 \mu \mathrm{m}$, which is abundant and constantly available in reef waters (e.g. Furnas et al. 1990, Ferrier-Pagès \& Gattuso 1998, Tada et al. 2003), are important nutrient sources for Oculina arbuscula. The use of stable isotopes, together with molecular trophic markers used by Leal et al. (2014a), contributes to the growing evidence that the small autotrophic and heterotrophic planktonic fraction importantly contributes to the nutrition of symbiotic scleractinian corals (Houlbrèque et al. 2004b, Naumann et al. 2009, Tremblay et al. 2012). These new data on the feeding preferences of symbiotic scleractinian corals may change our understanding of trophic interactions in coral reefs, because picoand nanoplankton have been overlooked as a potential food source for symbiotic corals.

Acknowledgements. M.C.L. was supported by a PhD scholarship (SFRH/BD/63783/2009) funded by the Fundação para a Ciência e Tecnologia (QREN-POPH-Type 4.1-Advanced Training, subsidized by the European Social Fund and national funds MCTES). Partial support was also provided by the US National Science Foundation to M.E.F. (awards OCE 0825999 and OCE 1031263), J.C.N. (award OCE 0824499) and J.A.B. (award OCE 1031263), and C.F.P was supported by the government of the Principality of Monaco. We are also grateful to G. McFall and NOAA's Gray's Reef National Marine Sanctuary for access to and help in collecting the corals used in this study, and to 3 anonymous reviewers for their comments. Oculina arbuscula corals were collected at Gray's Reef National Marine Sanctuary under the manager's permit.

\section{LITERATURE CITED}

ä Alamaru A, Yam R, Shemesh A, Loya Y (2009) Trophic biology of Stylophora pistillata larvae: evidence from stable isotope analysis. Mar Ecol Prog Ser 383:85-94

ä Anthony KRN, Fabricius KE (2000) Shifting roles of heterotrophy and autotrophy in coral energetics under varying turbidity. J Exp Mar Biol Ecol 252:221-253

ä Cocito S, Ferrier-Pagès C, Cupido R, Rottier C and others (2013) Nutrient acquisition in four Mediterranean gorgonian species. Mar Ecol Prog Ser 473:179-188

ä Fabricius KE, Benayahu Y, Genin A (1995) Herbivory in asymbiotic soft corals. Science 268:90-92

ä Fabricius K, Yahel G, Genin A (1998) In situ depletion of phytoplankton by an azooxanthellate soft coral. Limnol Oceanogr 43:354-356

ä Falkowski P, Dubinsky Z, Muscatine L, Porter J (1984) Light and the bioenergetics of a symbiotic coral. Bioscience 34 : 705-709

ä Ferrier-Pagès C, Gattuso JP (1998) Biomass, production and grazing rates of pico- and nanoplankton in coral reef waters (Miyako Island, Japan). Microb Ecol 35:46-57 
ä Ferrier-Pagès C, Witting J, Tambutt E, Sebens KP (2003) Effect of natural zooplankton feeding on the tissue and skeletal growth of the scleractinian coral Stylophora pistillata. Coral Reefs 22:229-240

Ferrier-Pagès $C$, Peirano $A$, Abbate $M$, Cocito $S$ and others (2011) Summer autotrophy and winter heterotrophy in the temperate symbiotic coral Cladocora caespitosa. Limnol Oceanogr 56:1429-1438

Fitt WK, McFarland FK, Warner ME, Chilcoat GC (2000) Seasonal patterns of tissue biomass and densities of symbiotic dinoflagellates in reef corals and relation to coral bleaching. Limnol Oceanogr 45:677-685

ä Fry B, Brand W, Mersch FJ, Tholke K, Garritt R (1992) Automated analysis system for coupled $\delta^{13} \mathrm{C}$ and $\delta^{15} \mathrm{~N}$ measurements. Anal Chem 64:288-291

ä Furnas MJ, Mitchell AW, Gilmartin M, Revelante N (1990) Phytoplankton biomass and primary production in semienclosed reef lagoons of the central Great Barrier Reef, Australia. Coral Reefs 9:1-10

ä Glynn PW (1973) Ecology of a Caribbean coral reef. The Porites reef-flat biotope: Part II. Plankton community with evidence for depletion. Mar Biol 22:1-21

ä Grottoli AG, Rodrigues LJ, Juarez C (2004) Lipids and stable carbon isotopes in two species of Hawaiian corals, Porites compressa and Montipora verrucosa, following a bleaching event. Mar Biol 145:1-11

ä Grottoli AG, Rodrigues LJ, Palardy JE (2006) Heterotrophic plasticity and resilience in bleached corals. Nature 440: 1186-1189

ä Houlbrèque F, Ferrier-Pagès C (2009) Heterotrophy in tropical scleractinian corals. Biol Rev Camb Philos Soc 84: $1-17$

ä Houlbrèque F, Tambutté E, Ferrier-Pagès C (2003) Effect of zooplankton availability on the rates of photosynthesis, and tissue and skeletal growth in the scleractinian coral Stylophora pistillata. J Exp Mar Biol Ecol 296:145-166

ä Houlbrèque F, Tambutte E, Allemand D, Ferrier-Pages C (2004a) Interactions between zooplankton feeding, photosynthesis and skeletal growth in the scleractinian coral Stylophora pistillata. J Exp Biol 207:1461-1469

ä Houlbrèque $F$, Tambutte $E$, Richard C, Ferrier-Pages C (2004b) Importance of a micro-diet for scleractinian corals. Mar Ecol Prog Ser 282:151-160

ä Houlbrèque F, Delesalle B, Blanchot J, Montel Y, FerrierPagès C (2006) Picoplankton removal by the coral reef community of La Prévoyante, Mayotte Island. Aquat Microb Ecol 44:59-70

ä Hughes AD, Grottoli AG (2013) Heterotrophic compensation: a possible mechanism for resilience of coral reefs to global warming or a sign of prolonged stress? PLoS ONE 8:e81172

ä Hughes AD, Grottoli AG, Pease TK, Matsui Y (2010) Acquisition and assimilation of carbon in non-bleached and bleached corals. Mar Ecol Prog Ser 420:91-101

Hunt J (1974) The geology and origin of Gray's Reef, Georgia continental shelf. MSc thesis, University of Georgia, Athens, GA

ä Hyland J, Cooksey C, Balthis WL, Fulton M, Bearden D, McFall G, Kendall M (2006) The soft-bottom macrobenthos of Gray's Reef National Marine Sanctuary and nearby shelf waters off the coast of Georgia, USA. J Exp Mar Biol Ecol 330:307-326

Lalli C, Parsons TR (1997) Biological oceanography: an introduction (2nd edn). Elsevier Butterworth-Heinemann, Oxford
Leal MC, Nunes C, Kempf SC, Reis A and others (2013) Effect of light, temperature and diet on the fatty acid profile of the tropical sea anemone Aiptasia pallida. Aquacult Nutr 19:818-826

Leal MC, Ferrier-Pagès $\mathrm{C}$, Calado $\mathrm{R}$, Thompson ME, Frischer ME, Nejstgaard JC (2014a) Coral feeding on microalgae assessed with molecular trophic markers. Mol Ecol (in press), doi:10.1111/mec.12486

Leal MC, Nejstgaard JC, Calado R, Thompson ME, Frischer ME (2014b) Molecular assessment of heterotrophy and prey digestion in zooxanthellate cnidarians. Mol Ecol (in press), doi:10.1111/mec.12496

ä Miller M (1995) Growth of a temperate coral: effects of temperature, light, depth, and heterotrophy. Mar Ecol Prog Ser 122:217-225

ä Muscatine L, McCloskey L, Marian R (1981) Estimating the daily contribution of carbon from zooxanthellae to coral animal respiration. Limnol Oceanogr 26:601-611

ä Muscatine L, Porter JW, Kaplan IR (1989) Resource partitioning by reef corals as determined from stable isotope composition. I. $\delta^{13} \mathrm{C}$ of zooxanthellae and animal tissue vs depth. Mar Biol 100:185-193

ä Muscatine L, Goiran C, Land L, Jaubert J (2005) Stable isotopes $\left(\delta^{13} \mathrm{C}\right.$ and $\left.\delta^{15} \mathrm{~N}\right)$ of organic matrix from coral skeleton. Proc Natl Acad Sci USA 102:1525-1530

ä Naumann MS, Richter C, el-Zibdah M, Wild C (2009) Coral mucus as an efficient trap for picoplanktonic cyanobacteria: implications for pelagic-benthic coupling in the reef ecosystem. Mar Ecol Prog Ser 385:65-76

ä Palardy JE, Grottoli AG, Matthews KA (2006) Effect of naturally changing zooplankton concentrations on feeding rates of two coral species in the Eastern Pacific. J Exp Mar Biol Ecol 331:99-107

ä Palardy JE, Rodrigues LJ, Grottoli AG (2008) The importance of zooplankton to the daily metabolic carbon requirements of healthy and bleached corals at two depths. J Exp Mar Biol Ecol 367:180-188

Parsons TR, Maita Y, Lalli CM (1984) A manual of chemical and biological methods for seawater analysis. Pergamon Press, Oxford

ä Piniak G (2002) Effects of symbiotic status, flow speed, and prey type on prey capture by the facultatively symbiotic temperate coral Oculina arbuscula. Mar Biol 141: 449-455

ä Piniak GA, Lipschultz F, McClelland J (2003) Assimilation and partitioning of prey nitrogen within two anthozoans and their endosymbiotic zooxanthellae. Mar Ecol Prog Ser 262:125-136

ä Porter JW (1976) Autotrophy, heterotrophy, and resource partitioning in Caribbean reef-building corals. Am Nat 110:731-742

R Development Core Team (2013) R: a language and environment for statistical computing. R Foundation for Statistical Computing, Vienna

ä Reynaud S, Ferrier-Pagés C, Sambrotto R, Juillet-Lecrec A, Jaubert J, Gattuso JP (2002) Effect of feeding on the carbon and oxygen isotopic composition in the tissues and skeleton of the zooxanthellate coral Stylophora pistillata. Mar Ecol Prog Ser 238:81-89

ä Reynaud S, Martinez P, Houlbrèque F, Billy I, Allemand D, Ferrier-Pagès C (2009) Effect of light and feeding on the nitrogen isotopic composition of a zooxanthellate coral: role of nitrogen recycling. Mar Ecol Prog Ser 392: 103-110

ä Ribes M, Coma R, Rossi S (2003) Natural feeding of the tem- 
perate asymbiotic octocoral-gorgonian Leptogorgia sarmentosa (Cnidaria: Octocorallia). Mar Ecol Prog Ser 254: $141-150$

ä Riera P (1998) $\delta^{15} \mathrm{~N}$ of organic matter sources and benthic invertebrates along an estuarine gradient in MarennesOléron Bay (France): implication for the study of trophic structure. Mar Ecol Prog Ser 166:143-150

ä Riera P, Richard P, Grémare A, Blanchard G (1996) Food source of intertidal nematodes in the Bay of MarennesOléron (France), as determined by dual stable isotope analysis. Mar Ecol Prog Ser 142:303-309

ä Riera P, Stal LJ, Nieuwenhuize J, Richard P, Blanchard G, Gentil F (1999) Determination of food sources for benthic invertebrates in a salt marsh (Aiguillon Bay, France) by carbon and nitrogen stable isotopes: importance of locally produced sources. Mar Ecol Prog Ser 187:301-307

ä Rocha RJM, Serôdio J, Leal MC, Cartaxana P, Calado R (2013) Effect of light intensity on post-fragmentation photobiological performance of the soft coral Sinularia flexibilis. Aquaculture 388-391:24-29

ä Rodolfo-Metalpa R, Richard C, Allemand D, Bianchi CN, Morri C, Ferrier-Pagès C (2006) Response of zooxanthellae in symbiosis with the Mediterranean corals Cladocora caespitosa and Oculina patagonica to elevated temperatures. Mar Biol 150:45-55

Rodrigues L, Grottoli A (2007) Energy reserves and metabolism as indicators of coral recovery from bleaching. Limnol Oceanogr 52:1874-1882

ä Sebens KP, Vandersall KS, Savina LA, Graham KR (1996) Zooplankton capture by two scleractinian corals, Madracis mirabilis and Montastrea cavernosa, in a field enclosure. Mar Biol 127:303-317

Editorial responsibility: Peter Edmunds, Northridge, California, USA ä Seemann J, Berry KL, Carballo-Bolaños R, Struck U, Leinfelder RR (2013) The use of ${ }^{13} \mathrm{C}$ and ${ }^{15} \mathrm{~N}$ isotope labeling techniques to assess heterotrophy of corals. J Exp Mar Biol Ecol 442:88-95

ä Swart PK, Saied A, Lam K (2005) Temporal and spatial variation in the $\delta^{15} \mathrm{~N}$ and $\delta^{13} \mathrm{C}$ of coral tissue and zooxanthellae in Montastraea faveolata collected from the Florida reef tract. Limnol Oceanogr 50:1049-1058

ä Tada K, Sakai K, Nakano Y, Takemura A, Montani S (2003) Size-fractionated phytoplankton biomass in coral reef waters off Sesoko Island, Okinawa, Japan. J Plankton Res 25:991-997

ä Tremblay P, Naumann MS, Sikorski S, Grover R, FerrierPagès C (2012) Experimental assessment of organic carbon fluxes in the scleractinian coral Stylophora pistillata during a thermal and photo stress event. Mar Ecol Prog Ser 453:63-77

ä Veal CJ, Carmi M, Fine M, Hoegh-Guldberg O (2010) Increasing the accuracy of surface area estimation using single wax dipping of coral fragments. Coral Reefs 29: 893-897

ä Verity PG, Yoder JA, Bishop SS, Nelson JR and others (1993) Composition, productivity and nutrient chemistry of a coastal ocean planktonic food web. Cont Shelf Res 13: 741-776

ä Verity PG, Paffenhofer GA, Wallace D, Sherr E, Sherr B (1996) Composition and biomass of plankton in spring on the Cape Hatteras shelf, with implications for carbon flux. Cont Shelf Res 16:1087-1116

ä Yahel R, Yahel G, Genin A (2005) Near-bottom depletion of zooplankton over coral reefs: I: Diurnal dynamics and size distribution. Coral Reefs 24:75-85

Submitted: October 11, 2013; Accepted: January 29, 2014 Proofs received from author(s): March 26, 2014 